\title{
ANALISIS PENGARUH PRICE TO BOOK VALUE, CURRENT RATIO, TINGKAT SUKU BUNGA DAN UKURAN PERUSAHAAN TERHADAP RETURN SAHAM PADA PERUSAHAAN YANG TERDAFTAR DI INDEKS KOMPAS 100 PERIODE 2012-2016
}

\author{
Aulia Nisa'. Khairunnisa ${ }^{2}$ \\ Universitas Telkom Bandung \\ aullianissa@gmail.com
}

\begin{abstract}
Stock return is an advantage received by investors for stock investment. The stock return of the Kompas 100 Index in 2012-2016 has fluctuated, so that it causes uncertainty that will be obtained by investors when carrying out stock investments in a company. This study aims to determine and analyze the effect of price to book value, current ratio, interest rates and company size on stock returns in companies listed in the Kompas 100 Index in 2012-2016. The analytical method used in the research is panel data regression. The results of this study indicate that the interest rate variable partially has a significant effect on stock returns. The price to book value, current ratio, and company size variables partially do not have a significant effect on stock returns. Simultaneously, the price to book value, current ratio, interest rates and company size variables have a significant influence on stock returns.
\end{abstract}

Keyword: Kompas 100 Index, Price to Book Value, Current ratio, Interest Rate, Firms Size, Stock Return

\begin{abstract}
ABSTRAK
Return saham merupakan keuntungan yang diterima investor atas investasi saham. Return saham Indeks Kompas 100 pada tahun 2012-2016 mengalami fluktuatif, sehingga hal tersebut menyebabkan adanya ketidakpastian yang akan didapatkan oleh investor ketika melalukan investasi saham di suatu perusahaan. Penelitian ini bertujuan untuk mengetahui dan menganalisa pengaruh price to book value, current ratio, tingkat suku bunga dan ukuran perusahaan terhadap return saham pada perusahaan yang terdaftar dalam Indeks Kompas 100 pada 20122016. Metode analisis yang digunakan dalam penelitian adalah regresi data panel. Hasil penelitian ini menunjukkan bahwa variabel tingkat suku bunga secara parsial memiliki pengaruh yang signifikan terhadap return saham. Variabel price to book value, current ratio, dan ukuran perusahaan secara parsial tidak memiliki pengaruh signifikan terhadap return saham. Secara simultan, variabel price to book value, current ratio, tingkat suku bunga dan ukuran perusahaan memiliki pengaruh yang signifikan terhadap return saham.
\end{abstract}

Kata Kunci: Indeks Kompas 100, Price to Book Value, Current Ratio, Tingkat Suku Bunga, Ukuran Perusahaan, Return Saham

\section{PENDAHULUAN}

Pertumbuhan ekonomi saat ini menjadi perhatian di setiap negara, begitupun di negara Indonesia. Untuk saat ini rata-rata perkembangan ekonomi Indonesia mendapat sumbangan kontribusi yang cukup besar dari sektor pasar modal. Menurut Herlianto (2013:10) pasar modal adalah sebagai tempat bertemunya pihak yang memiliki dana dengan pihak yang memerlukan dana jangka panjang (perusahaan). Pasar modal memberikan kemudahan dalam bertransaksi karena pembeli dan penjual tidak perlu bertemu langsung berkat adanya sistem perdagangan yang telah terkomputerisasi. Informasi yang dibutuhkan investor pun dalam bertransaksi dapat dengan mudah diakses. Dalam berinvestasi investor tentunya memperhitungkan seberapa banyak keuntungan yang bisa mereka dapatkan saat mereka melakukan investasi. Seperti yang dijelaskan oleh Kristiana dan Sriwidodo (2012) bahwa ekspektasi investor dalam berinvestasi 
saham selain menjadi pemilik suatu perusahaan dengan proposional kepemilikan tertentu, saham yang ditanamkan tersebut diharapkan mampu memberikan tingkat pengembalian atau return tertentu. Return saham adalah keuntungan yang dinikmati investor atas investasi saham yang dilakukan (Umam dan Sutanto, 2017:182).

Pada Kompas 100 tahun 2012 sampai 2016 mengalami fluktuatif, oleh karena terjadinya fluktuasi return saham maka hal tersebut melihatkan adanya ketidakpastian yang akan didapatkan oleh investor ketika melakukan investasi saham di suatu perusahaan, sehingga investor perlu mempertimbangkan kapan waktu mereka akan menjual atau membeli saham dengan secara rasional agar mendapatkan return saham sesuai dengan yang mereka inginkan. Untuk mendapatkan return saham yang sesuai dengan investor inginkan, maka investor harus memperhatikan faktor yang akan mempengaruhi return saham. Terdapat beberapa faktor yang harus investor perhatikan yaitu seperti variabel Price to Book Value (PBV), Current ratio (CR), tingkat suku bunga dan ukuran perusahaan.

Price to book value (PBV) merupakan rasio yang menunjukkan hasil perbandingan antara harga pasar per lembar saham dengan nilai buku perlembar saham (Hery, 2015:170). Semakin tinggi rasio PBV suatu perusahaan menunjukkan semakin tinggi pula penilaian investor terhadap perusahaan yang bersangkutan. Jika harga pasar saham semakin meningkat maka capital gain (actual return) dari saham tersebut juga meningkat (Putri dan Sumparno, 2012)

Current ratio (CR) menunjukkan sejauh mana aktiva lancar menutupi kewajibankewajiban lancar. Semakin besar perbandingan aktiva lancar dengan utang lancar semakin tinggi kemampuan perusahaan menutupi kewajiban jangka pendeknya (Harahap, 2015:301). Current ratio yang kecil akan menyebabkan penurunan harga saham perusahaan. Jika Current ratio yang dimiliki perusahaan semakin besar maka semakin besar pula kemampuan perusahan tersebut untuk memenuhi kebutuhan operasionalnya, khususnya modal kerja yang mana sangat penting untuk menjaga kinerja perusahaan yang pada akhirnya mempengaruhi harga saham. Hal ini akan memberikan keyakinan kepada investor untuk memiliki saham perusahaan tersebut sehingga akan meningkatkan return saham

Suku bunga adalah imbalan atas jasa pinjaman uang yang diberikan kepada pihak yang meminjam (Sujarweni, 2017:65). Menurut Dwialesi dan Darmayanti (2016) tingkat suku bunga SBI adalah instrumen yang digunakan BI dalam menstabilkan nilai rupiah. Mekanisme pelelangan SBI menggunakan acuan BI rate. BI rate yang semakin tinggi, menyebabkan investor akan beralih investasi dari sektor pasar modal ke investasi sektor perbankan. Menurunnya minat investor untuk berinvestasi di pasar modal akan berdampak pada penurunan harga saham dan menyebabkan return untuk investor menurun.

Besar kecilnya perusahaan menggambarkan ukuran perusahaan (Dwialesi dan Darmayanti, 2016). Menurut Sujoko dan Soebiantoro dalam Riningsih dan Putra (2015) firm size yang semakin besar mencerminkan pertumbuhan yang baik pada perusahaan tersebut yang dapat dilihat dari besarnya aset perusahaan. Jika aset yang dimiliki perusahaan semakin besar, investor akan memberikan nilai yang baik sehingga investor akan tertarik melakukan pembelian saham yang menyebabkan harga saham meningkat dan return saham yang diterima oleh investor meningkat.

\section{TINJAUAN PUSTAKA}

Pasar modal adalah tempat dimana berbagai pihak khususnya perusahaan menjual saham (stock) dan obligasi (bond) dengan tujuan dari hasil penjualan tersebut nantinya akan dipergunakan sebagai tambahan dana atau untuk memperkuat modal perusahaan (Fahmi, 2015:36).

Saham (stock) dapat didefinisikan sebagai tanda penyertaan atau pemilikan seseorang atau badan dalam satu perusahaan atau 
perseroan terbatas (Darmadji dan Fakhruddin, 2011:5).

Return merupakan salah satu faktor yang memotivasi investor untuk berinvestasi dan juga merupakan imbalan atas keberanian investor dalam menanggung risiko atas investasi tersebut. Setiap investasi yang menghasilkan pengembalian investasi yang tinggi juga akan disertai dengan berbagai risiko yang tinggi. Investasi merupakan pemilihan terhadap perimbangan antara risiko (risk) dan harapan keuntungan (expected return) yang terkait pada sebuah objek, maka investor perlu memperhatikan hal tersebut dengan baik dan penuh perhitungan (Herlianto, 2013:23). Return saham menggunakan capital gain dapat dihitung sebagai berikut (Umam dan Sutanto, 2017:183):

$$
\text { Return Saham }=\frac{\mathrm{P}_{1}-\mathrm{P}_{0}}{\mathrm{P}_{0}}
$$

Laporan keuangan adalah hasil dari proses akuntansi yang digunakan untuk mengkomunkasikan data keuangan perusahaan kepada pihak-pihak yang berkepentingan (Hary, 2015:3). Menurut Sujarweni (2017:12) laporan keuangan ada beberap jenis, yaitu neraca, laporan laba rugi, laporan perubahan modal, laporan arus kas dan laporan catatan atas laporan keuangan.

Analisis laporan keuangan berarti menggali lebih banyak informasi yang dikandung suatu laporan keuangan (Harahap, 2015:1). Dalam laporan keuangan terdapat beberapa rasio keuangan, diantaranya: rasio likuiditas, rasio solvabilitas, rasio aktivitas, rasio profitabilitas dan rasio penilain/rasio ukuran pasar.

Adapun variabel independen yang digunakan dalam penelitian ini adalah:

1. Rasio likuiditas

Rasio likuiditas yang digunakan dalam penelitian ini adalah rasio lancar (Current ratio). Rasio lancar menunjukkan sejauh mana aktiva lancar menutupi kewajiban-kewajiban lancar.
Semakin besar perbandingan aktiva lancar dengan utang lancar semakin tinggi kemampuan perusahaan menutupi kewajiban jangka pendeknya (Harahap, 2015:301).

Adapun rumus yang digunakan dalam menghitung Current Ratio sebagai berikut (Harahap, 2015:301):

$$
C R=\frac{\text { Aktiva Lancar }}{\text { Utang Lancar }}
$$

2. Rasio Penilaian/rasio ukuran pasar

Rasio penilaian/rasio ukuran pasar yang digunakan dalam penelitian ini adalah Price to Book Value. Price to book value menggambarkan seberapa besar pasar menghargai nilai buku saham suatu perusahaan. Makin tinggi rasio ini berarti pasar percaya akan prospek perusahaan tersebut (Darmadji dan Fakhruddin, 2011:157):

Adapun rumus yang digunakan dalam menghitung Price to book value sebagai berikut (Darmadji dan Fakhruddin, 2011:157):

$$
P B V=\frac{\text { HargaSaham }}{\text { Nilai Buku Saham }}
$$

3. Tingkat Suku Bunga

Suku bunga adalah imbalan atas jasa pinjaman uang yang diberikan kepada pihak yang meminjam (Sujarweni, 2017:65). Suku bunga diukur dengan rumus sebagai berikut (Makaryanawati dan Ulum, 2009):

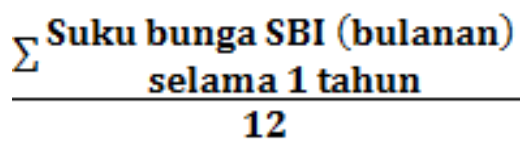

4. Ukuran Perusahaan

Besar kecilnya perusahaan menggambarkan ukuran perusahaan (Dwialesi dan Darmayanti. 2016). Menurut Hartono (2000:254) variabel ukuran perusahaan di ukur dengan 
logaritma natural (Ln) dari total aktiva karena besarnya total aktiva masingmasing perusahaan berbeda bahkan mempunyai selisih yang besar, sehingga dapat menyebabkan nilai yang ekstrim. Untuk menghindari adanya data yang tidak normal tersebut maka dari total aset perlu di Ln kan. Variabel ukuran perusahaan diproksikan dengan Ln total aktiva sehingga dapat dirumuskan

\section{Ukuran Perusahaan $=$ Ln $($ Total Aktiva $)$}

\section{METODE PENELITIAN}

Metode yang digunakan pada penelitian ini yaitu metode kuantitatif yang memusatkan perhatian pada gejala-gejela yang mempunyai karakteristik tertentu yang dinamakan variabel. Berdasarkan tujuan, penelitian ini menggunakan jenis penelitian deskriptif yaitu yang menggambarkan karakteristik atau fungsi dari suatu variabel tanpa melihat hubungan antar variabel (Indrawati, 2015:115). Berdasarkan tipe penyelidikan dalam penelitian ini yaitu penelitian kausal, dimana penelitian ini dilakukan untuk menggambarkan penyebab dari suatu masalah (Indrawati, 2015:117). Berdasarkan keterlibatan peneliti, penelitian ini tidak mengintervensi data karena penulis memperoleh data yang bersumber dari laporan keuangan tahunan perusahaan (Indrawati, 2015:117). Unit analisis yang digunakan dalam penelitian ini berfokus pada tingkat kelompok yaitu perusahaan yang konsisten terdaftar di Indeks Kompas 100 selama periode 2012-2016. Berdasarkan waktu pelaksanaan, penelitian ini menggunakan data panel dalam penelitiannya dikarenakan peneliti mengumpulkan secara berkala pada interval tertentu (Sujarweni. 2015:90). Metode pengumpulan data yang digunakan dalam penelitian ini adalah data dokumentasi (sekunder) yaitu dengan cara membaca, mengamati, mencatat, serta mempelajari uraian-uraian buku, jurnal-jurnal terdahulu terkait penelitian, dokumen laporan keuangan berupa rasio-rasio keuangan perusahaan yang terdaftar pada indeks Kompas 100 yang di unduh dari situs Bursa Efek Indonesia (www.idx.co.id), melihat harga saham penutup yang didapat dari situs saham $\mathrm{Ok}$ (www.sahamok.com) dan data tingkat suku bunga SBI periode 2012-2016 yang didapat dari situs BI (www.bi.go.id).

Populasi yang digunakan dalam penelitian ini adalah semua perusahaan yang terdaftar di Indeks Kompas 100 pada tahun 2012-2016. Sampel dalam penelitian ini diperoleh dengan menggunakan purposive sampling method dengan kriteria sebagai berikut:

a. Perusahaan yang konsisten terdaftar di Indeks Kompas 100 dari periode 2012 2016.

b. Perusahaan yang mempunyai persamaan perhitungan rasio dari perusahaan yang terdaftar pada periode $2012-2016$.

c. Perusahaan yang tidak melakukan corporate action.

Berdasarkan kriteria tersebut, diperoleh sampel sebanyak 31 perusahaan di Indeks Kompas 100 dengan waktu penelitian selama 2012-2016.

Analisis data yang digunakan pada penelitian ini menggunakan regresi data panel. Menurut Basuki dan Prawoto (2016:275), data panel adalah gabungan antara data runtut waktu (time series) dan data silang (cross silang). Persamaan model regresi data panel dapat ditulis sebagai berikut (Basuki dan Prawoto, 2016:276):

$$
\begin{aligned}
& \mathrm{Y}=a+b 1 X 1 i t+b 2 X 2 i t+b 3 X 3 i t+b 4 X 4 i t+ \\
&
\end{aligned}
$$

Keterangan:

$\mathrm{Y} \quad=$ Variabel dependen $(\mathrm{LDR})$

$\alpha \quad=$ Konstanta

$\mathrm{X} 1=$ Variabel independen 1

$\mathrm{X} 2=$ Variabel independen 2

$\mathrm{X} 3=$ Variabel independen 3

$\mathrm{X} 4=$ Variabel independen 4

$\mathrm{b}(1 \ldots 4)=$ Koefisien regresi masing-masing variabel independen 


$$
\begin{array}{ll}
\mathrm{e} & =\text { Error term } \\
\mathrm{t} & =\text { Waktu } \\
\mathrm{i} & =\text { Perusahaan }
\end{array}
$$

Berdasarkan variabel dependen dan variabel independen yang akan diteliti, maka model regresi data panel yang akan digunakan dalam penelitian ini dapat ditulis sebagai berikut:

Return $=\alpha+b 1 \mathrm{PBV}_{\mathrm{it}}+b 2 \mathrm{CR}_{\mathrm{it}}+b 3 \mathrm{Suku}$

Bunga $_{\text {it }}+b 4$ Ukuran Perusahaan $_{\text {it }}+\mathrm{e}$

Keterangan:

$\mathrm{PBV}=$ Price Book Value

$\mathrm{CR}=$ Current Ratio

\section{HASIL DAN PEMBAHASAN}

\section{Analisis Statistik Deskriptif}

Pada penelitian ini variabel terikat atau dependen yang digunakan adalah Return
Saham dan variabel bebas atau independen adalah Price to Book Value (PBV), Current Ratio (CR), tingkat suku bunga, dan ukuran perusahaan. Sampel yang digunakan dalam penelitian ini terdiri dari tiga puluh satu (31) perusahaan di Indeks Kompas 100 periode 2012-2016. Berikut disajikan tabel 1 berupa hasil perhitungan statistik deskriptif.

\begin{tabular}{cccccc}
\hline & PBV & CR & I & $\begin{array}{c}\text { Ukuran } \\
\text { Perusahaan }\end{array}$ & Return Saham \\
\hline Mean & 3,8264 & 2,3574 & 0,0666 & 25774401,13 & 0,1365 \\
Maximum & 62,9308 & 9,7169 & 0,0754 & 95197541 & 2,2913 \\
Minimum & 0,2576 & 0,4062 & 0,0577 & 2832000 & $-0,7908$ \\
$\begin{array}{c}\text { Std. Dev. } \\
\text { Observation }\end{array}$ & 9,1165 & 1,5623 & 0,0075 & 21731679,99 & 0,5271 \\
& 155,00 & 155 & 155 & 155 & 155 \\
\hline
\end{tabular}

Tabel 1

Hasil Analisis Statistik Deskriptif

Berdasarkan tabel 1 dapat di lihat nilai minimum dari Price to Book Value (PBV) yaitu sebesar 0,2576 yang terjadi pada perusahaan Medeo Energi Internasional Tbk (MEDC) pada tahun 2015. Nilai maksimum dari Price to Book Value (PBV) yaitu sebesar 62,9308 yang terjadi pada perusahaan Unilever Indonesia Tbk (UNVR) pada tahun 2016. Pada perusahaan yang menjadi sampel penelitian, hasil menunjukkan bahwa besar Price to book value (PBV) berkisar antara 0,2576 sampai 62,9308 dengan rata-rata (mean) 3,8264 dan standar deviasi 9,1165. Hal tersebut menunjukkan bahwa nilai rata-rata (mean)
PBV sebesar 3,8264 mengalami penyimpangan data sebesar 9,1165.

Berdasarkan tabel 1 dapat di lihat nilai minimum dari Current Ratio (CR) yaitu sebesar 0,4062 atau 40,62\% yang terjadi pada perusahaan Indosat Tbk (ISAT) pada tahun 2014. Nilai maksimum dari Current Ratio (CR) yaitu sebesar 9,7169 atau 971,69\% yang terjadi pada perusahaan Media Nusantara Citra Tbk (MNCN) pada tahun 2014. Pada perusahaan yang menjadi sampel penelitian, hasil menunjukkan bahwa besar Current ratio (CR) berkisar antara 40,62\% sampai 971,69\% dengan rata-rata (mean) $235,74 \%$ pada standar deviasi $156,23 \%$. Hal tersebut menunjukkan 
bahwa nilai rata-rata (mean) $\mathrm{CR}$ sebesar $235,74 \%$ mengalami penyimpangan data sebesar $156,23 \%$.

Berdasarkan tabel 1 dapat di lihat nilai minimum dari tingkat suku bunga yaitu sebesar 0,0577 atau $5,77 \%$ yang terjadi pada tahun 2012. Nilai maksimum dari tingkat suku bunga yaitu sebesar 0,0754 atau $7,54 \%$ yang terjadi pada tahun 2014. Pada perusahaan yang menjadi sampel penelitian, hasil menunjukkan bahwa besar tingkat suku berkisar antara $5,77 \%$ sampai $7,54 \%$ dengan rata-rata (mean) $6,66 \%$ pada standar deviasi $7,55 \%$. Hal tersebut menunjukkan bahwa nilai rata-rata (mean) tingkat suku bunga sebesar 6,66\% mengalami penyimpangan data sebesar $7,55 \%$.

Berdasarkan tabel 1 dapat di lihat nilai minimum dari total aset yaitu sebesar Rp. 2.832.000.000.000 yang terjadi pada perusahaan Lippo Cikarang Tbk (LPCK) pada tahun 2012. Nilai maksimum dari total aset yaitu sebesar Rp. 95.197.541.000.000 yang terjadi pada perusahaan Perusahaan Gas Negara (PGAS) pada tahun 2015. Pada perusahaan yang menjadi sampel penelitian, hasil menunjukkan bahwa besar total aset berkisar antara Rp. 2.832.000.000.000 sampai Rp. 95.197.541.000.000 dengan rata-rata (mean) Rp. 25.774.401.129.000 pada standar deviasi Rp. 21.731.679.990.700. Hal tersebut menunjukkan bahwa nilai rata-rata (mean) total aset sebesar Rp. 25.774.401.129.000 mengalami penyimpangan data sebesar Rp. 21.731.679.990.700.

Berdasarkan tabel 1 dapat di lihat nilai minimum dari Return Saham yaitu sebesar 0,7908 atau $-79,08 \%$ yang terjadi pada perusahaan Medeo Energi Internasional (MEDC) pada tahun 2012. Nilai maksimum dari Return Saham yaitu sebesar 2,2913 atau $229,13 \%$ yang terjadi pada perusahaan Adaro Energy Tbk (ADRO) pada tahun 2016. Pada perusahaan yang menjadi sampel penelitian, hasil menunjukkan bahwa besar Return Saham perusahaan yang menjadi sampel penelitian ini brekisar antara $-79,08 \%$ sampai $229,13 \%$ dengan rata-rata (mean) $13,65 \%$ pada standar deviasi $52,71 \%$, Hal tersebut menunjukkan bahwa nilai rata-rata (mean) return saham sebesar $13,65 \%$ mengalami penyimpangan data sebesar $52,71 \%$

Tabel 2

Hasil Uji Fixed Effect Model

Dependent Variable: Y

Method: Panel Least Squares

Date: 05/06/19 Time: 15:36

Sample: 20122016

Periods included: 5

Cross-sections included: 31

Total panel (balanced) observations: 155

\begin{tabular}{crrrr}
\hline \hline Variable & Coefficient & Std. Error & t-Statistic & Prob. \\
\hline \hline C & 9.358032 & 2.327808 & 4.020105 & 0.0001 \\
X1 & -0.000922 & 0.004609 & -0.200065 & 0.8418 \\
X2 & -0.026015 & 0.027355 & -0.951002 & 0.3435 \\
X3 & -120.8030 & 24.83322 & -4.864570 & 0.0000 \\
X4 & -0.036286 & 0.052274 & -0.694161 & 0.4889 \\
\hline \hline
\end{tabular}

Effects Specification

Cross-section fixed (dummy variables) 


\author{
Adjusted R-squared \\ S.E. of regression \\ Sum squared resid \\ Log likelihood \\ F-statistic \\ Prob(F-statistic)
}
0.204698
0.470097
26.51894
$-83.10412$
2.165800
0.001187

0.527135

1.523924

2.211149

1.803060

2.525171
Tabel 2 menunjukkan nilai konstanta koefisien yang dapat digunakan dalam membentuk persamaan regresi data panel. Adapun persamaan regresi data panel adalah sebagai berikut:

\section{Return = 9,3580 $-0,0009(P B V)-0,0260$$$
(C R)-120,8030 \text { (Suku Bunga) - 0,0363 }
$$

(Ukuran Perusahaan) + e

Persamaan regresi data panel tersebut memiliki nilai konstanta sebesar 9,3580 yang menunjukkan bahwa apabila Price to book value, Current ratio, tingkat suku bunga dan ukuran perusahaan bernilai konstan maka return saham akan bernilai 9,3580.

Koefisien regresi untuk variabel bebas Price to book value bernilai negatif, menunjukkan adanya hubungan yang tidak searah antara Price to book value dengan Return Saham. Koefisien regresi variabel Price to book value sebesar -0,0009 mengandung arti untuk setiap pertambahan Price to book value sebesar satu satuan akan menurunkan nilai Return Saham sebesar 0,0009 dengan asumsi bahwa variabel Current rati,o tingkat suku bunga dan ukuran perusahaan bernilai konstan.

Koefisien regresi untuk variabel bebas Current ratio bernilai negatif, menunjukkan adanya hubungan yang tidak searah antara Current ratio dengan Return Saham. Koefisien regresi variabel Current ratio sebesar -0,0260 mengandung arti untuk setiap pertambahan Current ratio sebesar satu satuan akan menurunkan nilai Return Saham sebesar 0,0260 dengan asumsi bahwa variabel Price to book value, tingkat suku bunga dan ukuran perusahaan bernilai konstan.

Koefisien regresi untuk variabel bebas tingkat suku bunga bernilai negatif, menunjukkan adanya hubungan yang tidak searah antara tingkat suku bunga dengan $n$ Saham. Koefisien regresi variabel tingkat suku bunga sebesar -120,8030 mengandung arti untuk setiap pertambahan tingkat suku bunga sebesar satu satuan akan menurunkan nilai Return Saham sebesar -120,8030 dengan asumsi bahwa variabel Price to book value, Current ratio dan ukuran perusahaan bernilai konstan.

Koefisien regresi untuk variabel bebas ukuran perusahaan bernilai negatif, menunjukkan adanya hubungan yang tidak searah antara ukuran perusahaan dengan Return Saham. Koefisien regresi variabel ukuran perusahaan sebesar $-0,0363$ mengandung arti untuk setiap pertambahan ukuran perusahaan sebesar satu satuan akan menurunkan nilai Return Saham sebesar 0,0363 dengan asumsi bahwa variabel Price to book value, Current ratio dan tingkat suku bunga bernilai konstan.

\section{Uji Hipotesis}

\section{a. Pengujian Hipotesis secara Simultan (Uji F)}

Berdasarkan hasil pengujian pada tabel 2 nilai pengujian secara simultan (uji F) sebesar 0,001187 yang berarti bahwa nilai tersebut lebih kecil daripada tingkat signifikansi 0,05 sehingga dapat diartikan bahwa Price to book value $\left(\mathrm{X}_{1}\right)$, Current ratio $\left(\mathrm{X}_{2}\right)$, Tingkat Suku Bunga $\left(\mathrm{X}_{3}\right)$ dan Ukuran Perusahaan $\left(\mathrm{X}_{4}\right)$ secara simultan memiliki pengaruh yang signifikan terhadap Return Saham.

\section{b. Pengujian Hipotesis Secara Parsial (Uji} t)

Berdasarkan tabel 2 diperoleh hasil uji secara parsial (uji t) sebagai berikut :

1. Nilai probabilitas price to book value sebesar 0,8418 dengan nilai koefisien sebesar -0,0009 menunjukkan bahwa 
nilai probabilitas tersebut lebih besar daripada tingkat signifikansi 0,05 . Nilai probabilitas tersebut menunjukkan bahwa $\mathrm{H}_{0}$ diterima, sehingga dapat dijelaskan bahwa price to book value tidak memiliki pengaruh yang signifikan terhadap return saham.

2. Nilai probabilitas current ratio sebesar 0,3435 dengan nilai koefisien sebesar $-0,0260$ menunjukkan bahwa nilai probabilitas tersebut lebih besar daripada tingkat signifikansi 0,05 . Nilai probabilitas tersebut menunjukkan bahwa $\mathrm{H}_{0}$ diterima, sehingga dapat dijelaskan bahwa current ratio tidak memiliki pengaruh yang signifikan terhadap return saham.

3. Nilai probabilitas tingkat suku bunga sebesar 0,0000 dengan nilai koefisien sebesar $-120,8030$ menunjukkan bahwa nilai probabilitas tersebut lebih kecil daripada tingkat signifikansi 0,05. Nilai probabilitas tersebut menunjukkan bahwa $\mathrm{H}_{0}$ ditolak, sehingga dapat dijelaskan bahwa tingkat suku bunga memiliki pengaruh yang signifikan terhadap return saham.

4. Nilai probabilitas ukuran perusahaan sebesar 0,4889 dengan nilai koefisien sebesar -0,0363 menunjukkan bahwa nilai probabilitas tersebut lebih besar daripada tingkat signifikansi 0,05 . Nilai probabilitas tersebut menunjukkan bahwa $\mathrm{H}_{0}$ diterima, sehingga dapat dijelaskan bahwa ukuran perusahaan tidak memiliki pengaruh yang signifikan terhadap return saham.

\section{c. Koefisien Determinasi}

Koefisien determinasi digunakan untu mengukur seberapa besar pengaruh variabel independen terhadap variabel dependen. Pada table 4.9 diperoleh nilai koefisien determinasi $\left(\mathrm{R}^{2}\right)$ sebesar 0,3803 atau 38,03\%. Hal ini menunjukkan bahwa Price to book value $\left(\mathrm{X}_{1}\right)$, Current ratio $\left(\mathrm{X}_{2}\right)$, Tingkat Suku Bunga $\left(\mathrm{X}_{3}\right)$ dan Ukuran Perusahaan $\left(\mathrm{X}_{4}\right)$ berpengaruh terhadap Return Saham (Y) sebesar 0,3803 atau 38,03\%. Sedangkan sisanya sebesar 0,6197 atau $61,97 \%$ dipengaruhi oleh variabel-variabel lainnya.

\section{KESIMPULAN}

Penelitian ini bertujuan untuk mengetahui analisis pengaruh price to book value, current ratio, tingkat suku bunga dan ukuran perusahaan terhadap return saham pada perusahaan yang terdaftar pada Indeks Kompas 100 periode 2012-2016. Jumlah sampel yang digunakan dalam penelitian ini sebanyak 31 perusahaan Indeks Kompas 100 dalam kurun waktu 5 tahun sehingga data yang diperoleh sebanyak 155 data. Berdasarkan hasil analisis statistik deskriptif dan hasil pengujian dengan menggunakan metode regresi linier berganda, maka diperoleh kesimpulan sebagai berikut:

1. Statistik Deskriptif.

a. Nilai rata-rata (mean) price to book value pada perusahaan yang terdaftar di Indeks Kompas 100 periode 20122016 mengalami tren yang cenderung menurun dari periode 2012-2016. Nilai minimum price to book value sebesar 0,2576 yang dimiliki oleh perusahaan Medeo Energi International Tbk (MEDC) pada tahun 2015 dan nilai maksimum sebesar 62,9308 yang dimiliki oleh perusahaan Unilever Indonesia Tbk (UNVR) pada tahun 2016.

b. Nilai rata-rata (mean) current ratio pada perusahaan yang terdaftar di Indeks Kompas 100 periode 20122016 mengalami tren yang cenderung menurun dari periode 2012-2016. Nilai minimum current ratio sebesar 0,4062 yang dimiliki oleh perusahaan Indosat Tbk (ISAT) pada tahun 2014 dan nilai maksimum sebesar 9,7169 yang dimiliki oleh perusahaan Media 
Nusantara Citra Tbk (MNCN) pada tahun 2014.

c. Nilai rata-rata (mean) tingkat suku bunga pada perusahaan yang terdaftar di Indeks Kompas 100 periode 20122016 cenderung mengalami tren yang meningkat dari periode 2012-2016. Nilai minimum tingkat suku sebesar 0,0577 atau $5,77 \%$ yang terjadi pada tahun 2012 dan nilai maksimum sebesar 0,0754 atau 7,54\% yang terjadi pada tahun 2014.

d. Nilai rata-rata (mean) ukuran perusahaan yang diukur dengan indicator total aset pada perusahaan yang terdaftar di Indeks Kompas 100 periode 2012-2016 mengalami tren yang meningkat dari periode 20122016. Nilai minimum ukuran sebesar Rp 2.832.000.000.000 yang dimiliki oleh perusahaan Lippo Cikarang Tbk (LPCK) pada tahun 2012 dan nilai maksimum sebesar Rp 95.197.541.000.000 yang dimiliki oleh Perusahaan Gas Negara (PGAS) pada tahun 2015.

e. Nilai rata-rata (mean) return saham pada perusahaan yang terdaftar di Indeks Kompas 100 periode 20122016 cenderung mengalami tren yang menurun dari periode 2012-2016 Nilai minimum return saham sebesar 0,7908 atau $-79,08 \%$ yang terjadi pada perusahaan Medeo Energi International Tbk (MEDC) pada tahun 2012 dan nilai maksimum sebesar 2,2913 atau $229,13 \%$ yang terjadi pada perusahaan Adaro Energy Tbk (ADRO) pada tahun 2016.

2. Price to book value (PBV), current ratio (CR), tingkat suku bunga, dan ukuran perusahaan memiliki pengaruh yang signifikan terhadap return saham pada perusahaan yang terdaftar di Indeks Kompas 100 periode 2012-2016.

3. Price to book value (PBV) tidak memiliki pengaruh yang signifikan terhadap return saham pada perusahaan yang terdaftar di Indeks Kompas 100 periode 2012-2016.

4. Current ratio (CR) tidak memiliki pengaruh yang signifikan terhadap return saham pada perusahaan yang terdaftar di Indeks Kompas 100 periode 2012-2016.

5. Tingkat suku bunga memiliki pengaruh yang signifikan terhadap return saham pada perusahaan yang terdaftar di Indeks Kompas 100 periode 2012-2016.

6. Ukuran perusahaan tidak memiliki pengaruh yang signifikan terhadap return saham pada perusahaan yang terdaftar di Indeks Kompas 100 periode 2012-2016.

\section{SARAN}

a. Penelitian ini diharapkan dapat memberikan referensi ke peneliti selanjutnya dan diharapkan peneliti selanjutnya dapat mengembangkan variabel-variabel independen dalam penelitian ini dengan indikator variabel lainnya seperti Debt to Equity Ratio (DER), Total Assets Turnover (TATO), Total Asset Turnover (TAT), Return on Asset (ROA), Return on Equity (ROE), Net Profit Margin (NPM), Earning Per Share (EPS), Price Earning Ratio (PER), Dividend per Share (DPS), inflasi, nilai tukar rupiah. Selain mengembangkan variabel independen, peneliti juga dapat menambahkan periode penelitian untuk memperoleh hasil dan kesimpulan yang berbeda dan terbaru supaya menambah wawasan peneliti dan pembaca.

b. Penelitian ini diharapkan dapat memberikan informasi yang cukup memadai sehingga dapat menambah pengetahuan dan wawasan khususnya dalam bidang manajemen keuangan mengenai pengaruh dari rasio keuangan terhadap return saham perusahaan yang nantinya akan diterima oleh investor.

c. Hasil penelitian ini menyarankan supaya investor berinvestasi pada perusahaan saat tingkat suku bunga menurun karena berdasarkan penelitian ini semakin menurun tingkat suku bunga maka akan 
semakin tinggi return saham yang diberikan perusahaan kepada investor.

\section{DAFTAR PUSTAKA}

Basuki, Agis Tri dan Nano Prawoto. (2016). Analisis Regresi dalam Penelitian Ekonomi \& Bisnis (Dilengkapi Aplikasi SPSS \& Eviews). Jakarta: Rajawali Pers.

Darmadji, Tjiptono dan Hendy M Fakhruddin. (2011). Pasar Modal di Indonesia. Jakarta: Salemba Empat.

Dwialesi, Juanita Bias dan Ni Putu Ayu Darmayanti. (2016). Pengaruh FaktorFaktor Fundamental terhadap Return Saham Indeks Kompas 100. E-Jurnal Manajemen Unud, Vol. 5, Nomor 9, ISSN: 2302-8912.

Fahmi, Irham. (2015). Pengantar Teori Portofolio dan Analisis Investasi Teori dan Soal Jawab. Bandung: Alfabeta.

Harahap, Sofyan Syafri. (2015). Analisis Kritis Atas Laporan Keuangan. Jakarta: PT RajaGrafindo Persada.

Hartono, Jogiyanto. (2000). Teori Portofolio dan Analisis Investasi. Yogyakarta: BPVE-UGM.

Herlianto, Didit. (2013). Manajemen Investasi Plus Jurus Mendeteksi Investasi Bodong. Yogyakarta: Pustaka Baru.

Hery. (2015). Analisis Laporan Keuangan. Yogyakarta: CAPS (Center for Academic Publishing Services).

Indrawati. (2015). Metode Penelitian Manajemen dan Bisnis Konvergensi Teknologi Komunikasi dan Informasi. Bandung: PT Refika Aditama.

Kristiana, Vera Anis dan Untung Sriwidodo. (2012). Analisis Faktor-faktor yang Mempengaruhi Return Saham Investor Pada Perusahaan Manufaktur di Bursa Efek Indonesia. Jurnal Ekonomi dan Kewirausahaan, Vol. 12 Nomor 1.

Makaryanawati dan Misbachul Ulum. (2009). Pengaruh Tingkat Suku Bunga dan Tingkat Likuiditas Perusahaan terhadap Risiko Investasi Saham yang
Terdaftar pada Jakarta Islamic Index. Jurnal Ekonomi Bisnis, Nomor 1, ISSN: 0853-7283.

Putri, Anggun Amelia Bahar dan R. Djoko Sampurno. (2012). Analisis Pengaruh ROA, EPS, NPM, DER dan PBV terhadap Return Saham (Studi kasus pada industry Real Estate and Property yang terdaftar di Bursa Efek Indonesia periode 2007-2009). Diponegoro Business Review, Vol. 1, Nomor 1.

Raningsih, Ni Kadek dan I Made Pande Dwiana Putra. (2015). Pengaruh Rasio-Rasio Keuangan dan Ukuran Perusahaan pada Return Saham. EJurnal Akutansi Universitas Udayana, Vol. 13, Nomor 2, ISSN: 2302-8556.

Sujarweni, V Wiratna (2015). Metodologi Penelitian Bisnis dan ekonomi. Yogyakarta: Pustaka Baru Press.

Sujarweni, V Wiratna. (2017). Manajemen Keuangan Teori, Aplikasi dan Hasil Penelitian. Yogyakarta: Pustaka Baru.

Umam, Khaerul dan Herry Sutanto. Manajemen Investasi. (2017). Bandung: Pustaka Setia. 